\title{
Teaching Media of Fiqh Magazine Model to Improve Prayer Understanding in Primary School Students
}

\author{
Moch. Bahak Udin By Arifin*, Nurdyansyah, Ida Rindaningsih, Imam Fauji \\ Faculty of Islamic Studies, Universitas Muhammadiyah Sidoarjo, Sidoarjo, Indonesia
}

Copyright $\bigcirc 2019$ by authors, all rights reserved. Authors agree that this article remains permanently open access under the terms of the Creative Commons Attribution License 4.0 International License

\begin{abstract}
This research develops Fiqh teaching media using a magazine model. Media teaching has an essential role in building the capacity of students to live and practice Islamic teachings, which later became the basis of the view of worship in his life. The material developed with the model of this magazine is Islamic primary school 2nd class prayer material (Madrasah Ibtidaiyah, Tarbiyatus Syarifah Pekarungan, Sidoarjo, Indonesia). The research method used is the Research and Development model. This research shows that learning media magazine models can reduce the level of students' boredom in learning because the format of design and writing is different and more interesting. Students are also more enthusiastic in learning, which can improve students' understanding.
\end{abstract}

Keywords Teaching Media, Fiqh Magazine Model, Improving Understanding, Primary School Students

\section{Introduction}

In the education system of Indonesia, there are religious subjects that are arranged according to the religion and adopted by students in each school. Students who advance the religion of Islam will get Islamic religious education subjects and conversely students who embrace Christianity will get a Christian education. Religion functions as a planter of values and controls the will, attitudes and behavior of a person in social life. With the very important function of religious education, there are still many problems that arising, especially related to learning, students are often bored and less enthusiastic in receiving religious education, especially Islamic education.

Islamic religious education is an education that reflects Islamic knowledge, characterized by the empowerment of the people, [1] sourced from the Qur'an [2] and hadith [3] [4]. This is what distinguishes Islamic education from other education. But that does not mean leaving various kinds of material, institutions, culture and its impact on the empowerment [5] of the people, but rather integrating them well and stand on the main sources namely Kalamullah and Kalamurrosulullah.

The advantages of Islamic education include that it can develop the potential of children optimally in terms of creativity [6]-[8], innovation [9], [10] and critical humanitarianism, and give birth to a generation that adheres to two sources of Islamic teachings [11].

Components forming the Islamic education [12] system include educators, students, subjects, methods, media, and evaluation. In one whole unit learning can be achieved if you find potential educators, able to use methods, and good media[13] to facilitate the delivery of learning.

One of the subjects in Islamic religious education is Fiqh. In language Fiqh comes from a word faqoha which means "comprehend" and "understand". In the term syar'inya [14] the science of Fiqh is a science that discusses various kinds of syar'i law Amali (practical), where the presenter uses the postulates that are studied and understood by the ijtihad [15] . Fiqh also has another meaning namely "deep understanding". As stated in the Qur'an, the letter in Taubah verse 122, which means [16]:

"Why do not go from each group among them, some people to deepen their knowledge of religion and to warn their people if they have returned to them, so that they it can take care of itself."

If "understanding" is often used for things that have an outward nature, then Fiqh contains an understanding that conveys zhahir knowledge to inner science. Therefore At Tirmidzi said "Fiqh about something" [17] means inner knowledge to its roots.

Running a learning process, including Fiqh learning [18], [19], requires interaction between educators, students and learning media to express good delivery strategies [11]. Moreover, media is the main strategy that is very influential on the success of learning activities of students [20]. That's a learning media [21], [22] becoming the main element in the delivery of strategies that can convey various messages to students, whether it is people, tools or materials in the form of media. 
Skinner expressed in his research that the strengthening operant conditioning of what has been learned is very important, if reinforcement runs optimally then learning can be said to be successful and complete [23]. Then good material processing and mastery of the material strongly supports the strengthening of material absorption for students in the learning process. Given the importance of strengthening learning materials [24]-[26] for students, the right media are needed to bridge an understanding that leads to the achievement of teaching and learning goals.

The Association for Education and Communication Technology (AECT) [27] explains that media as all forms used in the process of delivering information on the creative and innovative use of media [28]-[30] enables students to learn better and can improve understanding so that learning objectives are achieved. More than that, the media can overcome the various limitations of experience possessed by students, like the conditions of the classroom. With the use of media, it is possible to have direct interaction between students and the environment which creates uniformity and arouses curiosity as well as motivation [31]-[33] and interest [34], [35].

During the initial observation, the researchers found several problems in Islamic Primary Schools Tarbiyatus Syarifah Pekarungan, Sukodono, Indonesia. In the learning of Fiqh in class 2 the media used by educators were still driven by textbooks and student worksheets. Both of these media still lacked motivation, interest and understanding of students due to lack of interest and lack of variety in the appearance of text, color, image, evaluation and so on.

While students at the age of 8 years (class 2) are still in the concrete operational stage [36], [37], so that they need to learn media that are easy to understand, and able to stimulate the dimensions of children's knowledge. According to Piaget [38], at this stage the child has been able to understand various quantitative material, understand the classification of objects and their names, and multiply the classes of objects.

Even so, children aged 7-11 [39]-[41] [39] has some limitations in digesting an understanding, still thinking concretely, not being able to think abstractly and naturally. Things like this can be called operational, concrete stages of thinking.

Therefore, we need a more creative and interesting media that can motivate and improve students' understanding. The learning media [42] of the Fiqh magazine model are one of the print media that can be used as a reference material in teaching. Magazines are still new or rarely used in the use of learning media, which is actually able to reduce the level of boredom of students in learning, because the design and writing format are different and more interesting than textbooks or student worksheets.

The questions presented in this Fiqh learning magazine are various types. Ranging from the evaluation of comic models, evaluation of multiple choice models, evaluation of filling items and matching image stickers according to the text as well as Islamic reward stickers at the end of the question after knowing the answer key, all of which make learning more varied. Islamic and there is pride of students after being able to fill in the questions because they know the right answers and get reward stickers that can be taken by themselves.

The purpose of Fiqh magazine based media conducted by researchers is expected to have a positive impact and help improve student understanding so that learning objectives can be achieved optimally.

\section{Materials and Methods}

This research uses Research and Development model Borg and Gall [43], with the aim of developing a model where research findings are aimed at designing a product based on a procedure with 10 stages; (1) preliminary study and data collection, (2) planning (research objectives, time, research procedures, various forms of participation, (3) "developing preliminary form of product, (4) preliminary field testing, (5) playing product revision, (6) playing field testing, (7) revisions to compile operational products, (8) operational field testing, (9) field product revision (10) dissemination and implementation of product development.

Data collection techniques using expert jurisprudence magazine data feasibility, data effectiveness is only jurisprudence using students' activity observation sheets, and learning outcomes test validation sheets.

\subsection{Data from the Fiqh Magazine Expert Test Results}

Data content experts, who test results carried out using instruments questionnaires, see table 1. Test result data expert designs are made using instruments questionnaires, see table 2. Test result data of linguists who carried outused instruments questionnaires, see table 3 .

All data from the review Fiqih magazine expertly with content experts, design experts, and linguists were used as the basis for revising the improvement of the components of Fiqh magazine and content, before being tested on students as Fiqh magazine media users. 
Table 1. Test results of expert content

\begin{tabular}{|c|c|c|c|}
\hline No & Criteria & First test & Second test \\
\hline 1 & Attractiveness of media magazine cover & 84 & 96 \\
\hline 2 & Attractiveness of shape and size of the font is embedded in the cover of the magazine media & 75 & 88 \\
\hline 3 & The attractiveness and the suitability of images on the cover of the magazine media & 80 & 92 \\
\hline 4 & Attractiveness coloring pictures in a media magazine & 80 & 90 \\
\hline 5 & The composition of the colors used in media magazines & 84 & 92 \\
\hline 6 & The alignment of the image on the cover with the contents of the media magazine & 80 & 96 \\
\hline 7 & The clarity of images, characters in content media magazine & 75 & 92 \\
\hline 8 & Clarity depictions of events in media magazines & 75 & 88 \\
\hline 9 & Font type, size and layout used in media magazines & 84 & 96 \\
\hline 10 & The clarity of a topic that is poured in the form of pictures on a media magazine & 70 & 88 \\
\hline
\end{tabular}

Table 2. Test results of expert design

\begin{tabular}{|c|c|c|c|}
\hline No & Criteria & First test & Second test \\
\hline 1 & Attractiveness of media magazine cover & 84 & 96 \\
\hline 2 & Attractiveness of shape and size of the font is embedded in the cover of the magazine media & 75 & 88 \\
\hline 3 & The attractiveness and the suitability of images on the cover of the magazine media & 80 & 92 \\
\hline 4 & Attractiveness coloring pictures in a media magazine & 80 & 90 \\
\hline 5 & The composition of the colors used in media magazines & 84 & 92 \\
\hline 6 & The alignment of the image on the cover with the contents of the media magazine & 80 & 96 \\
\hline 7 & The clarity of images, characters in content media magazine & 75 & 92 \\
\hline 8 & Clarity depictions of events in media magazines & 75 & 88 \\
\hline 9 & Font type, size and layout used in media magazines & 84 & 96 \\
\hline 10 & The clarity of a topic that is poured in the form of pictures on a media magazine & 70 & 88 \\
\hline
\end{tabular}

Table 3. Test result linguist

\begin{tabular}{clcc}
\hline No & \multicolumn{1}{c}{ Criteria } & First test & Second test \\
\hline 1 & Accuracy of spelling used in media magazines & 82 & 96 \\
\hline 2 & The effectiveness of the sentence used in media magazines & 76 & 90 \\
\hline 3 & The precision of the punctuation used in media magazines & 72 & 92 \\
\hline 4 & Vocabulary used in media magazines & 80 & 92 \\
\hline 5 & Communicativeness of language used in media magazines & 72 & 88 \\
\hline
\end{tabular}

\subsection{Trial of Fiqh Magazine}

The trial of a large group involving 23 Islamic Primary School students (Madrasah Ibtidaiyah) Tarbiyatus Syarifah Sidoarjo Indonesia. The procedure for testing large groups is in accordance with the implementation plan of learning that has been made by the researcher. Based on the results of the questionnaire given to students, they agreed that the magazine's Fiqh media model made it easier for them to understand the material with picture illustrations, the attractiveness of animated images in magazine media, the clarity of the material and picture topics in magazine media, practicing illustrations of events in magazines, and the clarity of reading the text in magazine media, which is indicated by the percentage of each of these criteria is $100 \%$.

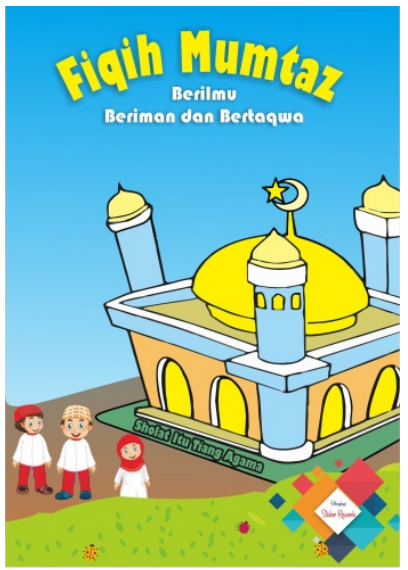

Figure 1. Cover teaching media of Fiqh magazine 

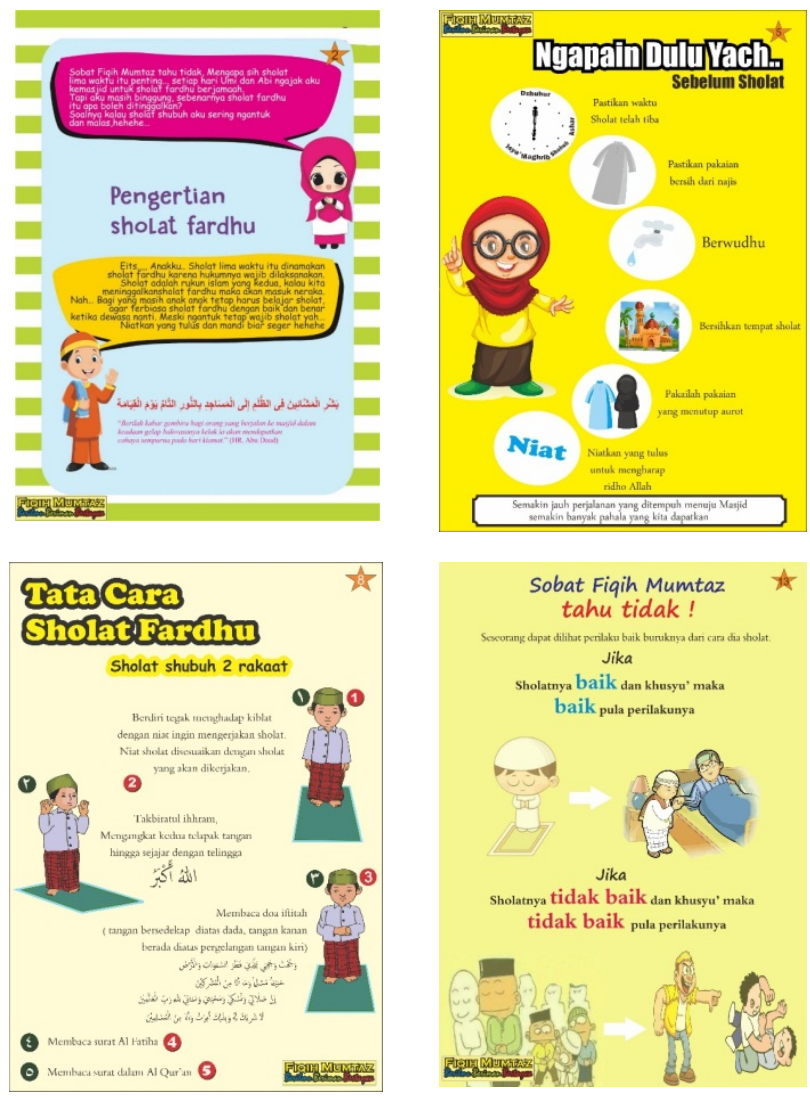

Figure 2. Teaching media of Fiqh magazine

While other criteria indicate that the material can be easily understood and can improve students' understanding. Can be seen as follows: 1) Title of magazine media (20 students answer yes and 3 answer no), with a percentage of $86.9 \%$. 2) Fonts used in magazine media (19 students answered yes and 4 students answered no), with a percentage of $82.6 \%$. 3) Drawing of the image of the presentation of the topic (21 students answered yes and 2 students answered no), with a percentage of $91.3 \%$. 4) Ease of understanding the questions on the evaluation question sheet (20 students answered yes and 3 students answered no), with a percentage of $86.9 \%$.

\subsection{Feasibility Test}

Table 4. Paired sample statistics

\begin{tabular}{|c|c|c|c|c|c|}
\hline & Mean & $\mathrm{N}$ & $\begin{array}{c}\text { Std. } \\
\text { Deviation }\end{array}$ & $\begin{array}{c}\text { Std. } \\
\text { Error } \\
\text { Mean }\end{array}$ \\
\hline \multirow{2}{*}{ Pair 1 } & pretest & 65.6522 & 23 & 14.94721 & 3.11671 \\
\cline { 2 - 6 } & posttest & 83.9130 & 23 & 12.51876 & 2.61034 \\
\hline
\end{tabular}

Table 5. Paired sample correlations

\begin{tabular}{|c|c|c|c|}
\hline & $\mathrm{N}$ & Correlation & Sig \\
\hline Pair 1 pretest \& Posttest & 23 & .860 & .000 \\
\hline
\end{tabular}

Based on the mean value or an average value in the table above, we can see the difference between the pretest and posttest learning outcomes, the pretest results show an average value of 65.65 and the results posttest shows an average value of 83.91. Therefore the static $t$-value p-value is 0.00 which means $(<0.05)$, it can be concluded that Ho is rejected and Ha is accepted. This means that there is a significant influence on the average value of the pretest and posttest.

This data also shows that there is a significant increase in the average understanding of students after receiving new treatment, namely the application of Fiqh magazine model media.

\subsection{Effectiveness Test}

Figure 6. Model Summary

\begin{tabular}{|c|c|c|c|c|}
\hline Model & $\mathrm{R}$ & R Square & Adjusted R Square & $\begin{array}{c}\text { Std. Error of } \\
\text { The Estimate }\end{array}$ \\
\hline 1 & $.404^{\mathrm{a}}$ & .163 & .123 & 11.72257 \\
\hline
\end{tabular}

Predictors : (Constant), fiqh magazine model

$\mathrm{R}=0.404$ the magnitude of the coefficient. Correlation between teaching media Fiqh magazine model (independent variable) with students' understanding of posttest (dependent variable)

$\mathrm{R}$ Square of 0.163 means $16.3 \%$. This shows that changes in student learning outcomes are determined by teaching media Fiqh magazine models by $16.3 \%$. While the $83.7 \%$ increase in understanding of students is determined by other variables outside the variables in this study. So that an interpretation can be made that the textbook model of children's comics is quite influential in increasing the understanding of class II students in the study of Figh prayer material in Islamic Primary School Tarbiyatus Syarifah Sidoarjo Indonesia.

\subsection{Discussion}

The learning environment has a significant impact on the successful implementation of the Fiqh magazine model teaching media. Because the condition of the classrooms is quite large with adequate ventilation, making students feel at home studying in the classroom, so that students become focused on participating in the learning activities carried out.

The condition of class 2 Islamic Primary School Tarbiyatus Syarifah Sidoarjo, Indonesia, very heterogeneous, there are students who are classified as smart and there are also students who are classified as less intelligent, there are students who are active and there are also students who are passive. In addition, these 2 nd grade students come from a variety of different kindergartens, with a background of knowledge that is certainly different. The condition of students like this is very helpful for the successful application of learning by using teaching media in the Fiqh magazine model. When grade 2 students enter the concrete operational stage, they are happier with the 
learning media, which has interesting and illustrated topics, so that it is easier to understand. Because the selection of topics in magazines made by researchers takes the theme of everyday life so that students can better imagine the conditions that occur.

The teaching media for the magazine model had a considerable influence on the success of this study. Because having a topic and content that is not boring is also raised from the phenomenon that is happening. The use of magazine teaching media also helps students not to get bored by reading books that only contain writings with few images.

Readiness of teachers and researchers is also a factor that supports the success of learning media in the magazine model. Besides having to prepare instruments in learning activities the teacher must also master the material to be delivered, must be able to control and condition the class. When there are students who still tend to be passive in learning activities, educators must immediately take action by asking students to ask questions, answer questions or help explain to other students. In addition, educators also approach individually to students so they do not feel awkward in learning activities.

\section{Conclusions}

Based on the research and development process for the teaching media of Fiqh magazine models for grade 2 this can be said to have good quality. This is because the use of Fiqh teaching media in this magazine model can help improve student understanding and attractiveness of learning, so that it helps facilitate students to improve student learning outcomes.

\section{REFERENCES}

[1] K. Zaelani, "Philosophy of science actualization for Islamic science development," Pacific Sci. Rev. B Humanit. Soc. Sci., vol. 1, no. 3, pp. 109-113, 2015.

[2] Z. Salma, "Tanggungjawab Orangtua Dalam Membentuk Kepribadian Anak Perspektif Alquran dan Psikologi," $A L$ QUDS J. Stud. Alquran dan Hadis, vol. 1, no. 1, p. 67, 2017.

[3] A. H. Nufus, "Pengantar dan Sejarah Perkembangan Ilmu Hadits." Center for Open Science, 2018.

[4] F. Iman, "ILMU TAKHRIJ AL-HADITS," ALQALAM, vol. 10, no. 52, p. 31, 1995.

[5] I. Amaliah, T. Aspiranti, and P. Purnamasari, "The Impact of the Values of Islamic Religiosity to Islamic Job Satisfaction in Tasikmalaya West Java, Indonesia, Industrial Centre," Procedia - Soc. Behav. Sci., vol. 211, no. September, pp. 984-991, 2015.
[6] C. Richardson and P. Mishra, "Learning environments that support student creativity: Developing the SCALE," Think. Ski. Creat., vol. 27, pp. 45-54, Mar. 2018.

[7] T. Bertoncelli, O. Mayer, and M. Lynass, "Creativity, Learning Techniques and TRIZ," Procedia CIRP, vol. 39, pp. 191-196, Jan. 2016.

[8] J. Mierdel and F. X. Bogner, "Is creativity, hands-on modeling and cognitive learning gender-dependent?," Think. Ski. Creat., vol. 31, pp. 91-102, Mar. 2019.

[9] W. Admiraal et al., "Teachers in school-based technology innovations: A typology of their beliefs on teaching and technology," Comput. Educ., vol. 114, pp. 57-68, Nov. 2017.

[10] Z. C. Y. Chan, "Student peer reviewers' views on teaching innovations and imaginative learning," Nurse Educ. Today, vol. 39, pp. 155-160, Apr. 2016.

[11] M. F. Ashaari et al., "An Assessment of Teaching and Learning Methodology in Islamic Studies," Procedia - Soc. Behav. Sci., vol. 59, pp. 618-626, Oct. 2012.

[12] M. A. Lubis, M. M. Yunus, M. A. Embi, S. Sulaiman, and Z. Mahamod, "Systematic Steps in Teaching and Learning Islamic Education in the Classroom," Procedia-Soc. Behav. Sci., vol. 7, pp. 665-670, Jan. 2010.

[13] Nurdyansyah, S. Masitoh, B. S. Bachri, and Istikomah, "Problem solving in learning mathematics through ILMo model," Int. J. Eng. Technol., vol. 7, no. 3.4 Special Issue 4, pp. 325-328, 2018.

[14] J. Juliati and M. Firman, "SIKAP PERILAKU KESEHARIAN MASYARAKAT DAN LINGKUNGAN KELUARGA SEBAGAI CERMIN KEBERHASILAN CITIZENSHIP EDUCATION," SALAM J. Sos. dan Budaya Syar-i, vol. 3, no. 3, 2018.

[15] M. A. Mughal, "An Ijtihad is Not Annulled by a Like Ijtihad," SSRN Electron. J., 2012.

[16] M. Q. Shihab, Tafsir Al-Mishbah. Jakarta: Lentera Hati, 2002.

[17] A. Syarifuddin, Garis Garis Besar Fiqih. Jakarta: Kencana, 2003.

[18] M. Abdurrahman and D. Rosyidin, "Concept of Tarbiyah (Education) in Al-Quran - Semantic-Sociological Study Based on Various Verses of Al-Quran," 2nd International Conference on Sociology Education. SCITEPRESS Science and Technology Publications, 2017.

[19] A. Alhamuddin, F. F. R. S. Hamdani, D. Tandika, and R. Adwiyah, "DEVELOPING AL-QURAN INSTRUCTION MODEL THROUGH 3A (AJARI AKU AL-QURAN OR PLEASE TEACH ME AL-QURAN) TO IMPROVE STUDENTS' ABILITY IN READING AL-QURAN AT BANDUNG ISLAMIC UNIVERSITY," Int. J. Educ., vol. 10, no. 2, 2018.

[20] S. M. Al-karasneh and A. M. J. Saleh, "Islamic perspective of creativity: A model for teachers of social studies as leaders," Procedia - Soc. Behav. Sci., vol. 2, no. 2, pp. 412 426, Jan. 2010.

[21] B. H. Stephenson, "New Media and Learning," The Routledge International Handbook of Children, 
Adolescents and Media. Routledge.

[22] M. Chen, "Children and families in the digital age: learning together in a media saturated world," J. Child. Media, pp. $1-4,2019$.

[23] B. F. Skinner, "The operant side of behavior therapy," $J$. Behav. Ther. Exp. Psychiatry, vol. 19, no. 3, pp. 171-179, Sep. 1988.

[24] L. D. Zimmerman and G. Calovini, "Toys as Learning Materials for Preschool Children," Except. Child., vol. 37, no. 9, pp. 642-654, 1971.

[25] L. Galisdorfer, "New Learning Materials for Partially Sighted Children," J. Except. Child., vol. 16, no. 4, pp. 109$113,1950$.

[26] "Young Children Learning," Young Children Learning. Blackwell Publishing Ltd, pp. 209-225.

[27] M. J. B. J. Michael Spector, M. David Merrill, Jan Elen, Handbook of Research on Educational Communications and Technology, Fourth edi. Bloomington: Springer Science, 2014.

[28] S. Chalovska and C. Plavevska, "INNOVATIVE CREATIVE LEARNING IN EARLY CHILDHOOD EDUCATION," EDULEARN18 Proceedings. IATED, 2018.

[29] E. Heck, "Social learning and the facilitation of co-creative media practice in community media, arts and cultural organisations," Queensland University of Technology.

[30] K. A. Peppler and Y. B. Kafai, "From SuperGoo to Scratch: exploring creative digital media production in informal learning," Learn. Media Technol., vol. 32, no. 2, pp. 149166, 2007.

[31] P. Reed, "Learning and Motivation, Editorial," Learn. Motiv., vol. 65, p. A1, 2019.

[32] W. J. Davis, "Motivation and learning: Neurophysiological mechanisms in a 'model' system," Learn. Motiv., vol. 15, no. 4, pp. 377-393, 1984.

[33] A. Martin and N. Guéguen, "Repeating what children say positively influences their learning and motivation," Learn. Motiv., vol. 52, pp. 48-53, 2015.

[34] A. W. Nizami and A. Mahmudi, "Problem-solving-based learning to improve students' learning interest." Author(s), 2018.

[35] H. Leung, "Enhancing students' ability and interest in geometry learning through geometric constructions," The University of Hong Kong Libraries.

[36] D. W. Winnicott, "Ego Integration in Child Development," Oxford Clinical Psychology. Oxford University Press, 2016.

[37] L. L'Abate, "Frequency of Citation in Child Psychology Literature," Child Dev., vol. 40, no. 1, p. 87, 1969.

[38] J. Piaget, “Commentary on Vygotsky's criticisms of language and thought of the child and judgment and reasoning in the child," New Ideas Psychol., vol. 13, no. 3, pp. 325-340, Nov. 1995.

[39] J. Piaget, "Reason," New Ideas Psychol., vol. 24, no. 1, pp.
1-29, Apr. 2006.

[40] J. Piaget, "Structuralism (Psychology Revivals)." Psychology Press, 2015.

[41] G. Fireman and G. Kose, "Piaget, Vygotsky, and the Development of Consciousness," Recent Research in Psychology. Springer US, pp. 369-376, 1990.

[42] H. Fikri, A. S. Madona, and Y. Nora, "Development of Instructional Media for Teaching Bahasa Indonesia through Interactive Multimedia Based on Response of Trends in Using Instructional Media by the Students and Teachers during the Learning Process," 1st International Conference on Educational Sciences. SCITEPRESS - Science and Technology Publications, 2017.

[43] W. B. M. D. Gall, Educational Research an Introduction. New York: Logman, 1983. 